\title{
BACTERIOLOGY OF WOUNDS INFECTIONS IN A TERTIARY CARE HOSPITAL
}

\author{
Suguneswari Giddi1 ${ }^{1}$ Dasari Sarada², Sisisra $D^{3}$
}

${ }^{1}$ Associate Professor, Department of Microbiology, Viswabharathi Medical College, Kurnool.

${ }^{2}$ Assistant Professor, Department of Microbiology, Viswabharathi Medical College, Kurnool. ${ }^{3}$ Assistant Professor, Department of Microbiology, Viswabharathi Medical College, Kurnool.

\section{ABSTRACT}

Wound infections are one of the leading causes of patient's morbidity, which ends in financial loss to both patient and hospital. Delayed treatment drug resistance due to indiscriminate use of antibiotics is implicated as the cause of chronicity of wounds. Empirical treatment without culturing the causative agent somehow lessens the delay of treatment, but actually is leading to the rise of resistant strains in the community. It is obligatory to know the prevalence of causative agents to implicate the early treatments without wait for the culture reports.

\section{MATERIAL AND METHODS}

This study was done to identify the prevalent organisms of wounds and its susceptibility to antimicrobials. 100 pus samples from different wounds of 100 patients, both inpatients and outpatients attending Viswabharathi Medical College at Kurnool were collected. All the pus samples were processed by gram staining of the direct smear, inoculating on to nutrient agar, blood agar, and MacConkey agar and incubated overnight at $37^{\circ} \mathrm{c}$. Culture morphology and gram staining was done from the positive growth Confirmation was done by biochemical reactions and necessary special tests. Results: 100 wound samples yielded 105 isolates. Among the total 105 isolates, the gram negative isolates were dominating and accounted for $53.33 \%$ and gram positive accounted for $46.66 \%$ only. In the overall study, Staphylococcus remained as predominant isolate and is $100 \%$ sensitive to vancomycin, Linezolid.

\section{CONCLUSION}

The accurate identification of culture isolates may be a useful tool to provide appropriate antibiotic and help in reducing the drug-resistant strains in wound infections. This study provides better guidance for the clinicians to cure wounds without delay and much waste of antibiotics that ultimately prevents the resistant strains and saves the economy of both patient as well as hospital.

\section{KEYWORDS}

Wounds, Antimicrobial Susceptibility, Staphylococcus, Gram-Negative Bacilli.

HOW TO CITE THIS ARTICLE: Giddi S, Sarada D, Sisisra D. Bacteriology of wounds infections in a tertiary care hospital. J. Evolution Med. Dent. Sci. 2016;5(55):3763-3766, DOI: 10.14260/jemds/2016/862

\section{INTRODUCTION}

Wound infections are one of the most common hospitalacquired infections and accounts for $70-80 \%$ mortality due to the prolonged morbid conditions. ${ }^{1}$ Skin is one of the major obstacles for the establishment of infection by pathogens in the internal tissue. After microbial invasion, skin loses its integrity and the subcutaneous tissues provide a moist, warm and nutritious environment for the microbial colonization. ${ }^{2}$ Development of wound infection leads patients towards a longer stay in hospitals, which ultimately causes discomfort, mental stress, and also affects the patient's productivity in terms of work capability. This causes financial constraints both to the patient and the hospital. ${ }^{1}$ Wound infections are treatment complicated because of development of drug resistance due to providence of treatment without analysing the causative agent and its susceptibility pattern. ${ }^{3}$ it in turn becomes necessary to prevent wound infections by analysing the most common etiological agent and highly susceptible drug to prevent drug misuse.

Financial or Other, Competing Interest: None.

Submission 03-05-2016, Peer Review 28-06-2016,

Acceptance 04-07-2016, Published 09-07-2016.

Corresponding Author:

Dr. Suguneswari Giddi,

Associate Professor

Department of Microbiology,

Viswabharathi Medical College,

Kurnool District.

E-mail: doctorsuguna@gmail.com

DOI: $10.14260 /$ jemds $/ 2016 / 862$
The focus of our study was to know the etiology of surgical wounds in a teaching hospital and analyse its antibiotic susceptibility and resistance patterns. This study also provides a better ground for the clinicians to treat wound infections empirically without delay.

\section{MATERIALS AND METHODS}

This study was conducted in Viswabharathi Medical College located at Kurnool, Andhra Pradesh, India from a period of October 2014 to September 2015. The studied population belonged to all age groups irrespective of sex who were admitted in the hospital with various types of wounds (Trauma, Postoperative, Ulcers, Burns, Abscess, Boil, and Cellulitis) shown in Table 3. A total of 100 patients were studied and 100 samples (Drained or aspirated pus, pus swabs, and wound tissue) were collected and cultured for the causative agents by direct smear, culture on to blood, nutrient, and MacConkey agar and incubated at $37^{\circ} \mathrm{c}$ for 24 hours. The culture plates were processed for organisms by gram staining and by using standard diagnostic biochemical reactions. All the isolates were subjected to conventional biochemical methods (Like Indole production test, Methyl red test, Voges-Proskauer test, Citrate utilisation test, Urease test, Triple Sugar Iron test, Sugar fermentation tests, Coagulase test, Oxidase test, and Catalase test) in accordance to the standard microbiological techniques. All MRSA strains are detected by using Oxacillin and Methicillin discs shown in Table 4. In order to determine the antibiogram, all the isolates were subjected to antibiotic 
sensitivity testing by Kirby-Bauer's disc diffusion technique by using Mueller-Hinton agar media. Commercially available antibiogram disc are tested in a Petri plate with MuellerHinton agar seeded with test inoculum and read after overnight incubation by measuring the zone of inhibition and results are interpreted according to the clinical and laboratory standard institute guidelines (CLSI). ${ }^{4}$

\section{RESULTS}

In this study, patients of all age groups were considered and out of 85 culture positives, $70(82.35 \%)$ were males and 15 (17.64\%) were females. Among 100 specimens, growth was obtained from 85 samples (85\%) and total isolates identified were 105. Among the 105 isolates, single isolates were identified from 65 specimens and two organisms isolated from 20 specimens. Among the 65 single isolates, Staphylococcus aureus accounts for 37 isolates (56.92\%), followed by Pseudomonas aeruginosa for 12 isolates (18.46\%), Escherichia coli 8 (12.31\%), Proteus vulgaris 5 (7.69\%), and Klebsiella pneumonia for 3 isolates (4.62\%) (Table-2).

The frequency of gram-positive verses gram-negative isolates among single isolates were $56.92 \%$ followed by gramnegative isolates of $43.07 \%$ out of 65 isolates. In mixed cultures, gram-negative organisms were dominated over gram positive isolates. Out of 40 mixed isolates, $28(70 \%)$ isolates were gram-negative and gram-positive isolates accounted 12 (30\%) only (Table-2).

By combining the results of total 105 isolates the gramnegative isolates were dominating and accounted for $53.33 \%$ and gram positive accounted $46.66 \%$ only. In the overall study, Staphylococcus remained as dominant isolate. The results of culture positivity and details of the isolates were shown in the Table-1.

All the isolates were subjected to antimicrobial sensitivity by Kirby-Bauer's technique and observed varied results among gram-positive and gram-negative isolates. Staphylococcus showed maximum resistance to Penicillin (91.30\%), Erythromycin (89.13\%), and Gentamicin (86.95\%) and $100 \%$ percent sensitivity for Amikacin, Vancomycin, and Linezolid. The results of antibiotic susceptibility of all the isolates were shown in the (Table-4) and (Table-5). Among the gram-negative isolates, maximum resistance was observed for Gentamicin (87.61) and Ampicillin (58.82\%) and maximum sensitivity to Imipenem (100\%), Amikacin (72.73\%). The most resistant organism noted was Pseudomonas aeruginosa, as it exhibited resistance to multiple drugs as always.

\begin{tabular}{|c|c|c|c|}
\hline $\begin{array}{c}\text { Total } \\
\text { Wound } \\
\text { Cases }\end{array}$ & $\begin{array}{c}\text { Culture } \\
\text { Positive }\end{array}$ & $\begin{array}{c}\text { Culture } \\
\text { Negative }\end{array}$ & Total \\
\hline Males & $70(82.35 \%)$ & $7(46.66 \%)$ & $77(77 \%)$ \\
\hline Females & $15(17.64 \%)$ & $8(53.33 \%)$ & $23(23 \%)$ \\
\hline Total & $\mathbf{8 5 ( 8 5 \% )}$ & $\mathbf{1 5 ( 1 5 \% )}$ & $\begin{array}{c}\mathbf{1 0 0} \\
\mathbf{( 1 0 0 \% )}\end{array}$ \\
\hline
\end{tabular}

Table 1: Prevalence of Culture Positivity in Wound Infections

Chi square $=9.16 \mathrm{p}$ value $=0.002$ significant

\begin{tabular}{|c|c|}
\hline $\begin{array}{c}\text { Single Isolate from } 65 \\
\text { Specimens } \\
\text { Isolate/No/Percentage } \\
(76.47 \%) \\
\end{array}$ & $\begin{array}{c}\text { Two Isolates from } 20 \\
\text { Specimens } \\
\text { Isolate/No/Percentage } \\
(23.52 \%) \\
\end{array}$ \\
\hline $\begin{array}{l}\text { Staphylococcus aureus (37) } \\
(56.92 \%)\end{array}$ & $\begin{array}{c}\text { Escherichia coli and } \\
\text { Pseudomonas spp (5) } \\
(25 \%)\end{array}$ \\
\hline $\begin{array}{l}\text { Escherichia coli (12) } \\
(12.31 \%)\end{array}$ & $\begin{array}{l}\text { Staphylococcus aureus and } \\
\text { Pseudomonas (4) (20\%) }\end{array}$ \\
\hline $\begin{array}{l}\text { Pseudomonas aeruginosa } \\
\text { (8) }(18.46 \%)\end{array}$ & $\begin{array}{c}\text { Escherichia coli and } \\
\text { Klebsiella pneumoniae (3) } \\
(15 \%)\end{array}$ \\
\hline $\begin{array}{l}\text { Proteus vulgaris (5) } \\
(7.69 \%)\end{array}$ & $\begin{array}{c}\text { Escherichia coli and } \\
\text { Staphylococcus aureus (3) } \\
(15 \%)\end{array}$ \\
\hline $\begin{array}{l}\text { Klebsiella pneumoniae (3) } \\
(4.62 \%)\end{array}$ & $\begin{array}{c}\text { Pseudomonas species and } \\
\text { Staphylococcus } \\
\text { epidermidis (3) (15\%) }\end{array}$ \\
\hline & $\begin{array}{c}\text { Klebsiella pneumoniae and } \\
\text { Staphylococcus aureus (2) } \\
(10 \%)\end{array}$ \\
\hline \multicolumn{2}{|c|}{$\begin{array}{l}\text { Table 2: Outline of Isolates in } 85 \\
\text { Culture Positive Specimens }\end{array}$} \\
\hline
\end{tabular}

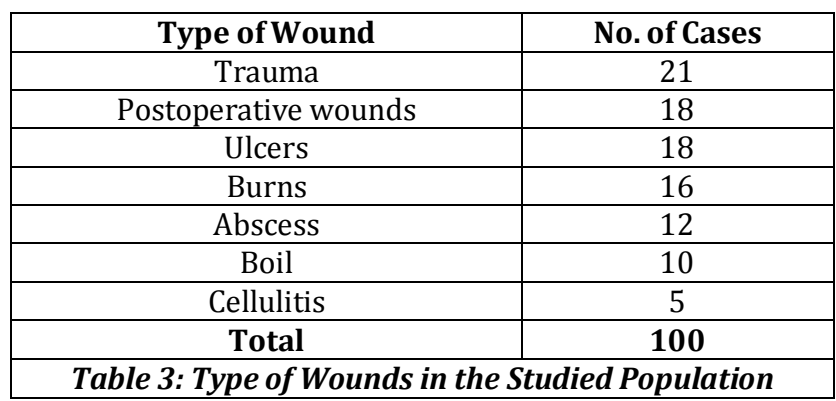

\begin{tabular}{|c|c|c|c|c|}
\hline Antimicrobial Drugs & \multicolumn{2}{|c|}{ Staphylococcus Aureus (46) } & \multicolumn{2}{c|}{ Staphylococcus Epidermidis (3) } \\
\hline & Sensitivity(S) & Resistance(R) & Sensitivity(S) & Resistance(R) \\
\hline Penicillin(10unit) & $8.69 \%(\mathrm{n}: 4)$ & $91.30 \%(\mathrm{n}: 42)$ & $0(\mathrm{n}: 0)$ & $100 \%(\mathrm{n}: 3)$ \\
\hline Erythromycin(15mcg) & $10.86 \%(\mathrm{n}: 5)$ & $89.13 \%(\mathrm{n}: 41)$ & $0(\mathrm{n}: 0)$ & $100 \%(\mathrm{n}: 3)$ \\
\hline Ciprofloxacin(5mcg) & $21.73 \%(\mathrm{n}: 10)$ & $78.26 \%(\mathrm{n}: 36)$ & $66.66 \%(\mathrm{n}: 2)$ & $33.33 \%(\mathrm{n}: 1)$ \\
\hline Methicillin(5mcg) & $30.43 \%(\mathrm{n}: 14)$ & $69.56 \%(\mathrm{n}: 32)$ & $0(\mathrm{n}: 0)$ & $100 \%(\mathrm{n}: 3)$ \\
\hline Vancomycin(5mcg) & $100 \%(\mathrm{n}: 46)$ & $0(\mathrm{n}: 0)$ & $100 \%(\mathrm{n}: 3)$ & $0(\mathrm{n}: 0)$ \\
\hline Oxacillin(1mcg) & $32.60 \%(\mathrm{n}: 15)$ & $67.39 \%(\mathrm{n}: 31)$ & $66.66 \%(\mathrm{n}: 2)$ & $33.33 \%(\mathrm{n}: 1)$ \\
\hline Amikacin(30mcg) & $100 \%(\mathrm{n}: 46)$ & $0(\mathrm{n}: 0)$ & $100 \%(\mathrm{n}: 3)$ & $0(\mathrm{n}: 0)$ \\
\hline Linezolid(10mcg) & $100 \%(\mathrm{n}: 46)$ & $0(\mathrm{n}: 0)$ & $100 \%(\mathrm{n}: 3)$ & $0(\mathrm{n}: 0)$ \\
\hline Cefepime(30mcg) & $28.26 \%(\mathrm{n}: 13)$ & $71.73 \%(\mathrm{n}: 33)$ & $66.66 \%(\mathrm{n}: 2)$ & $33.33 \%(\mathrm{n}: 1)$ \\
\hline Gentamicin(10mcg) & $13.04 \%(\mathrm{n}: 6)$ & $86.95 \%(\mathrm{n}: 40)$ & $33.33 \%(\mathrm{n}: 1)$ & $66.66 \%(\mathrm{n}: 2)$ \\
\hline
\end{tabular}




\begin{tabular}{|c|c|c|c|c|c|c|c|c|}
\hline \multirow[b]{2}{*}{ AMD } & \multicolumn{2}{|c|}{$\begin{array}{c}\text { Escherichia Coli } \\
\text { (n:23) }\end{array}$} & \multicolumn{2}{|c|}{$\begin{array}{c}\text { Klebsiella spp } \\
\text { (n:8) }\end{array}$} & \multicolumn{2}{|c|}{$\begin{array}{c}\text { Pseudomonas spp } \\
\text { (n:20) }\end{array}$} & \multicolumn{2}{|c|}{$\begin{array}{c}\text { Proteus spp } \\
\text { (n:5) }\end{array}$} \\
\hline & $\mathrm{S}$ & $\mathrm{R}$ & $\mathrm{S}$ & $\mathrm{R}$ & $\mathrm{S}$ & $\mathrm{R}$ & $\mathrm{S}$ & $\mathrm{R}$ \\
\hline $\mathrm{A}(10 \mathrm{mcg})$ & $\begin{array}{c}19.04 \% \\
\text { (n:4) }\end{array}$ & $\begin{array}{c}80.95 \% \\
\text { (n:17) }\end{array}$ & $\begin{array}{l}60 \% \\
(\mathrm{n}: 6)\end{array}$ & $\begin{array}{l}40 \% \\
(n: 4)\end{array}$ & $\begin{array}{l}41.66 \% \\
\text { (n:10) }\end{array}$ & $\begin{array}{l}58.34 \% \\
(\mathrm{n}: 14)\end{array}$ & $\begin{array}{l}40 \% \\
(2)\end{array}$ & $\begin{array}{l}60 \% \\
(n: 3)\end{array}$ \\
\hline $\mathrm{G}(10 \mathrm{mcg})$ & $\begin{array}{l}9.52 \% \\
(\mathrm{n}: 2)\end{array}$ & $\begin{array}{l}90.47 \% \\
\text { (n:19) }\end{array}$ & $\begin{array}{l}20 \% \\
(\mathrm{n}: 2)\end{array}$ & $\begin{array}{l}80 \% \\
(n: 8)\end{array}$ & $\begin{array}{c}0 \\
\text { (n: } 0)\end{array}$ & $\begin{array}{l}100 \% \\
\text { (n:24) }\end{array}$ & $\begin{array}{l}20 \% \\
\text { (n:1) }\end{array}$ & $\begin{array}{l}80 \% \\
(\mathrm{n}: 4)\end{array}$ \\
\hline $\mathrm{AK}(30 \mathrm{mcg})$ & $\begin{array}{l}80.95 \% \\
\text { (n:17) }\end{array}$ & $\begin{array}{c}19.05 \% \\
\text { (n:4) }\end{array}$ & $\begin{array}{l}80 \% \\
(n: 8)\end{array}$ & $\begin{array}{l}20 \% \\
(\mathrm{n}: 2)\end{array}$ & $\begin{array}{l}50 \% \\
(12)\end{array}$ & $\begin{array}{l}50 \% \\
(\mathrm{n}: 12)\end{array}$ & $\begin{array}{l}80 \% \\
(n: 4)\end{array}$ & $\begin{array}{l}20 \% \\
(\mathrm{n}: 1)\end{array}$ \\
\hline $\mathrm{C}(5 \mathrm{mcg})$ & $\begin{array}{c}28.57 \% \\
\text { (n:6) }\end{array}$ & $\begin{array}{l}71.43 \% \\
\text { (n:15) }\end{array}$ & $\begin{array}{l}50 \% \\
(n: 5)\end{array}$ & $\begin{array}{l}50 \% \\
(n: 5)\end{array}$ & $\begin{array}{l}37.5 \% \\
\text { (n:9) }\end{array}$ & $\begin{array}{l}62.5 \% \\
(\mathrm{n}: 15)\end{array}$ & $\begin{array}{l}20 \% \\
\text { (n:1) }\end{array}$ & $\begin{array}{l}80 \% \\
(\mathrm{n}: 4)\end{array}$ \\
\hline $\mathrm{Ce}(30 \mathrm{mcg})$ & $\begin{array}{c}14.28 \% \\
(\mathrm{n}: 3)\end{array}$ & $\begin{array}{c}85.72 \% \\
\text { (n:18) }\end{array}$ & $\begin{array}{l}50 \% \\
(n: 5)\end{array}$ & $\begin{array}{l}50 \% \\
(n: 5)\end{array}$ & $\begin{array}{l}8.33 \% \\
\text { (n:2 }\end{array}$ & $\begin{array}{l}91.66 \% \\
\text { (n:22) }\end{array}$ & $\begin{array}{l}40 \% \\
(\mathrm{n}: 2)\end{array}$ & $\begin{array}{l}60 \% \\
(\mathrm{n}: 3)\end{array}$ \\
\hline $\mathrm{I}(10 \mathrm{mcg})$ & $\begin{array}{l}100 \% \\
(\mathrm{n}: 21)\end{array}$ & $\begin{array}{c}0 \\
(\mathrm{n}: 0)\end{array}$ & $\begin{array}{l}100 \% \\
(\mathrm{n}: 10)\end{array}$ & $\begin{array}{c}0 \\
(\mathrm{n}: 0)\end{array}$ & $\begin{array}{l}100 \% \\
(\mathrm{n}: 24)\end{array}$ & $\begin{array}{c}0 \\
(\mathrm{n}: 0)\end{array}$ & $\begin{array}{l}100 \% \\
(\mathrm{n}: 5)\end{array}$ & $\begin{array}{c}0 \\
(\mathrm{n}: 0)\end{array}$ \\
\hline $\mathrm{PZ}(100 / 10 \mathrm{mcg})$ & $\begin{array}{c}66.66 \% \\
(\mathrm{n}: 14)\end{array}$ & $\begin{array}{c}33.34 \% \\
\text { (n:7) }\end{array}$ & $\begin{array}{l}40 \% \\
\text { (n: } 4)\end{array}$ & $\begin{array}{l}60 \% \\
(\mathrm{n}: 6)\end{array}$ & $\begin{array}{c}25 \% \\
(6)\end{array}$ & $\begin{array}{c}75 \% \\
(\mathrm{n}: 18)\end{array}$ & $\begin{array}{l}60 \% \\
(n: 3)\end{array}$ & $\begin{array}{l}40 \% \\
(\mathrm{n}: 2)\end{array}$ \\
\hline
\end{tabular}

AMD-Antimicrobial drugs, A-Ampicillin, G-Gentamicin, AK-Amikacin, C-Ciprofloxacin, CE-Cefuroxime, I-Imipenem, PZPiperacillin/Tazobactam.

\section{DISCUSSION}

Wound infection has become a major burden to healthcare providers as it may act as a barrier to provide cost-effective treatment and increases the financial burden to the patient along with trauma. ${ }^{3}$ The financial constraints limit the patient to go for serial wound cultures so as to make the clinicians be based on the empirical treatment that itself leading to the resistant strains in the community. ${ }^{5}$ This study was conducted to analyse the incidence of wounds, causative agents, and its antibiogram so that it would be a guide for empirical treatment to the clinicians.

The predominant bacteria identified in the wounds of the studied patients are gram-negative isolates (53.33\%) over gram-positive isolates (46.66\%), which coincides with the study of Aizza Zafar, Naeem Anwar ${ }^{1}$, and Ramesh Rao, S. Sumathi ${ }^{6}$. In contrast to the studies with Sanjay Dhar, Rakesh Saraf $^{5}$ and Ana Kaftandzieva, Zhaklina Cekovska ${ }^{7}$ where grampositive isolates were predominated. Male preponderance was observed in this study that coincides with the study of Ohalete. C.N, Obi. R.K $\mathrm{K}^{3}$ and Aizza Zafar, Naeem Anwar ${ }^{1}$. The predominant organism identified in 105 isolates was Staphylococcus aureus even though the percentage of gramnegative isolates were high, which coincides with the previous studies and stating that though there was dominance of gramnegative isolates observed in this study, Staphylococcus aureus remained a predominant isolate $8,9,5,7,1,10,3,6$. This study contrasts with the study done by P.R.Fa-Si-Oen, et al ${ }^{11}$ where Escherichia coli dominance was reported. In gram-negative isolates, Pseudomonas was identified as a predominant isolate followed by Escherichia coli, which coincides with the studies done by Sanjay Dhar, Rakesh Saraf et al5, and Gayathree Nail, Srinivas R et $\mathrm{al}^{12}$ and with Ohalete. C.N, Obi. R.K et $\mathrm{al}^{3 \text {, and }}$ Ramesh Rao, S. Sumathi et al. ${ }^{6}$

After studying the antibiogram of the isolates, Vancomycin, Linezolid, Amikacin, and Imipenem were proved effective and Penicillin, Erythromycin, Gentamicin, and Ampicillin were most resistant drugs. Wide usage of vast number of broadspectrum antibiotics maybe allowing the changing pattern of drug susceptibility of the microorganisms. Selection of the appropriate antibiotic by culture and antibiotic susceptibility of the isolates would limit rising the resistant strains. Continuous wound irrigation and debridement along with proper antibiotic choice would limit the prevalence of wound infections in the community.

\section{CONCLUSIONS}

Wound infections are one of the significant causes of morbidity of patients. Staphylococcus aureus remained the predominant causative agent of wounds and is $100 \%$ sensitive to Vancomycin, Linezolid, and Imipenem. Inappropriate use of antibiotics is one of the most important causes of rising resistant strains and would be limited by following the regular culture and sensitivity testing of isolates in the wounds. Eradication of wound infections cannot be accomplished completely, but reduction could be possible by continuous irrigation and debridement of wound along with treatment with appropriate antibiotics.

\section{ACKNOWLEDGEMENTS}

The authors are thankful to the Chairman, Principal, and Superintendent of Viswabharathi Medical College for their encouragement. The authors are also thankful to the technical staff for their cooperation in the department.

\section{REFERENCES}

1. Zafar A, Anwar N, Ejaz H. Bacteriology of infected wounds-a study conducted at children's hospital Lahore. Biomedica 2008;24:71-4.

2. Giacometti A, Cirioni O, Schimizzi AM, et al. Epidemiology and microbiology of surgical wound infection. Journal of Clinical Microbiology 2000;38(2):918-22.

3. Ohalete CN, Obi RK, Emea KMC. Bacteriology of different wound infection and their antimicrobial susceptibility patterns in IMO state Nigeria. World Journal of Pharmaceutical Sciences 2012;1(3):1155-72.

4. Clinical and Laboratory Standard Institute. Performance standards for antimicrobial susceptibility testing. CLSI Wayne, 24th Informational Supplement 2014.

5. Dhar S, Saraf R, Singh K, et al. Microbiological profile of chronic burn wounds among patients admitted in burn unit. JK Science 2007;9(4):182-5.

6. Rao RS, Sumathi K, Anuradha D, et al. Bacteriology of postoperative wound infections. International Journal of Pharmaceutical and Biomedical Research 2013;4(2): 72-6. 
7. Kaftandzieva A, Cekovska Z, Igor K, et al. Bacteriology of wound-clinical utility of Gram stain microscopy and correlation with culture. Macedonian Journal of Medical Sciences 2012;5(1):72-7.

8. Tanni LOA, Osniupedi OA, Deji Agboola M. Prevalence of bacterial pathogens in infected wounds in a tertiary hospital,1995-2001: any change in trends? J Natl Med Assoc 2003;95(12):1189-95.

9. Surucuoglu S, Gazi H, Kurutepe S, et al. Bacteriology of surgical wound infections in a tertiary care hospital in Turkey. East Afr Med J 2005;82(7):331-6.

10. Goswami NN, Trivedi HR, Goswami AP, et al. Antibiotic sensitivity profile of bacterial pathogens in postoperative wound infections at a tertiary care hospital in Gujarat, India. J Pharmacol Pharmacother 2011;2(3):158-64.
11. Fa-Si-Oen PR, Kroeze F, Verhoef LHM, et al. Bacteriology of abdominal wounds in elective open colon surgery: a prospective study of 100 surgical wounds. Clinical Microbiology and Infection 2005;11(2):155-7.

12. Naik G, Deshpande SR. A study on surgical site infections caused by Staphylococcus aureus with a special search for methicillin-resistant isolates. Journal of Clinical and Diagnostic Research 2011;5(3):502-8. 